\title{
二光子励起で放出制御可能な一酸化窒素放出剤
}

\author{
菱川和宏, 中川秀彦, 宮田直 樹*
}

\section{Nitric Oxide Donors Activated by Two-Photon Excitation}

\author{
Kazuhiro HishiKawa, Hidehiko NAKAgAwa, and Naoki MiYATA* \\ Graduate School of Pharmaceutical Science, Nagoya City University, 3-1 Tanabe-dori, \\ Mizuho-ku, Nagoya 467-8603, Japan
}

(Received August 5, 2010)

\begin{abstract}
Nitric oxide (NO) is a key molecule in blood pressure regulation, neuromodulation, and biodefense. Since it is an unstable gas under ambient conditions, various NO donors have been developed and employed for biological studies as an alternative to direct NO application. However, many of them release NO via spontaneous decomposition, so that it is difficult to control the NO release. Therefore, NO donors from which NO release can be temporally and spatially wellcontrolled by means of photoexcitation offer considerable advantages. Various NO donors from which NO release is activated by photoirradiation have been reported. However, the maximum absorption of these NO donors is generally limited to the UV or short-wavelength visible light range, which does not adequately penetrate living tissues. To overcome this limitation, NO donors working via two-photon excitation (TPE) were developed by Ford and Prasad, based on NO release from Fe-nitrosyl complex. We have also developed TPE-type NO donors based on our photo-controllable 2,6-dimethylnitrobenzene derivatives, and investigated their NO-releasing properties. Here, we present an overview of photocontrollable NO donors and discuss their properties in relation to biological applications.
\end{abstract}

Key words — nitric oxide donor; caged compound; two-photon excitation; photoinduced release; two-photon uncaging cross section

\section{1. はじめに}

窒素原子と酸素原子の二原子からなる一酸化窒素 (NO) は常温常圧で無色無臭の気体であり，その 構造中に不対電子を有するフリーラジカルである. 元々は大気污染物質の 1 つとして捉えられていた NO だが，血管内皮由来驰緩因子（EDRF）として 血管弛緩作用を示すことが発見されて以降，免疫応 答や神経伝達などに係わる重要な因子であることが 示されている. ${ }^{1-7)}$

しかし，NO はその反応性の高さから直接生物試 験に用いることは容易ではなく，生理的条件下で $\mathrm{NO}$ を放出する NO 放出剤（NO ドナー）が用いら れてきた。 ${ }^{8)}$ ころが，これまでに報告されている NO ドナーは自発分解でNO 放出を起こすものがほ とんどであり，放出させる時間・場所が制御できる

名古屋市立大学大学院薬学研究科（T467-8603 名古屋 市瑞穂区田辺通 3-1)

*e-mail: miyata-n@ phar.nagoya-cu.ac.jp

本総説は, 日本薬学会第 130 年会シンポジウム GS04

で発表したものを中心に記述したものである.
NO ドナーが必要とされてきた.

そのような中で, 時空間的に放出制御ができる NO ドナーとして, 光照射により NO 放出を起こす 化合物がいくつか報告されている，光照射で NO 放出をコントロールできる化合物は研究用試薬とし てだけではなく, 光線力学療法の治療薬としての応 用も期待できる.

以下に光作動型 NO ドナーについて例を示して 説明する.

2. 光照射により放出制御が可能な NO ドナー

2-1. CNO 類9) DEA/NO (diethylamine/NO) は自発分解で NO 放出を起こすことが知られてい る NONOateの1つである（Fig. 1)。Keefer らは $\mathrm{DEA} / \mathrm{NO}$ の様々な誘導体を合成し，1位の酸素を アルキル化した化合物は自発分解せずNO 放出を 起こさないことを報告した. ${ }^{10,11)}$ これに基づき Tsien らは DEA/NOの 1 位の酸素に光分解性保護基であ る 2-nitrobenzyl 基を導入した CNO 類を開発した.

汎用される代表的な CNO 類である CNO-4 では $365 \mathrm{~nm}$ におけるモル吸光係数は $\varepsilon_{365 \mathrm{~nm}}=3700 \mathrm{M}^{-1}$ 


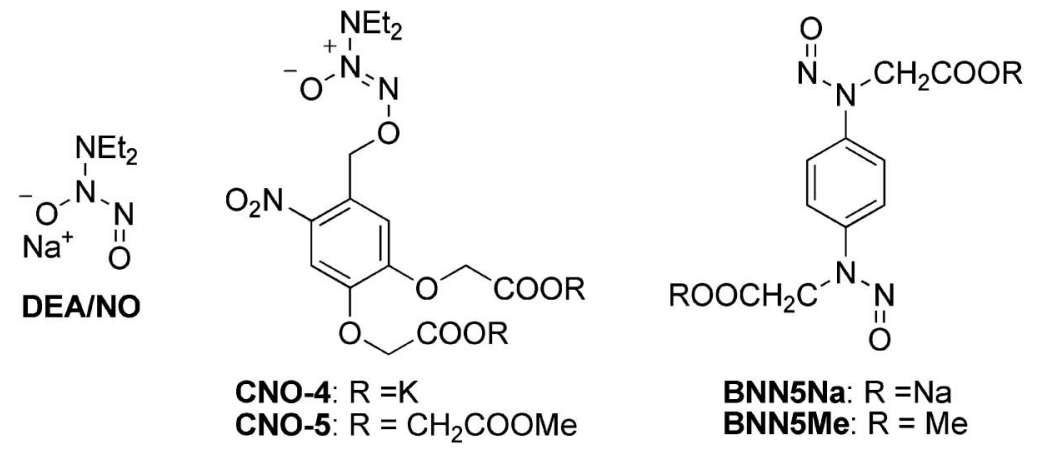

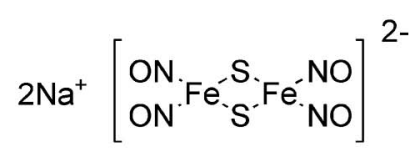

Roussin's red salt

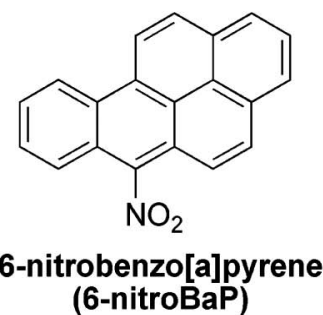

Fig. 1. Structures of NO Donors Working with One-photon Excitation $\mathrm{cm}^{-1}$ であり $\mathrm{NO}$ 放出の量子収率は $\Phi=0.01$ であ る。また，CNO-4には細胞膜透過性が低いという 問題点があり，それを改善するためにプロドラッグ 化を行った CNO-5が開発されている.

$\mathrm{CNO}$ 類の光作動型 NO ドナーは総じて水溶性が 低く，また NO 放出の量子収率が低いという久点 がある。

\section{2-2. BNN 類 ${ }^{12,13)}$ BNN (Bis- $N$-nitroso）類化} 合物は Fujimori らにより開発された光作動型 NO ドナーである（Fig. 1). ${ }^{12)}$ その構造は $N, N^{\prime}$-dinitroso- $p$-phenylenediamine 骨格を有し，1つの分子 から 2 つの NO 分子が生成するという特徵がある.

汎用される代表的な BNN 類である BNN5Na は $300 \mathrm{~nm}$ におけるモル吸光係数は $\varepsilon_{300 \mathrm{~nm}}=13500 \mathrm{M}^{-1}$ $\mathrm{cm}^{-1}$ であり $\mathrm{NO}$ 放出の量子収率は $\Phi=1.87$ である (一分子の BNN5Na から二分子の NO が放出され るため量子収率は 1 より大きくなる)。また， BNN5Na は細胞膜透過性が低いという問題点があ り，それを改善した BNN5M が開発されている. ${ }^{13)}$
2-3. 金属-ニトロシル錯体金属一ニトロシル

錯体も光作動型 NO ドナーとなることが知られて いる。例えば鉄-硫黄一ニトロシルである Roussin's black salt (RBS) や Roussin's red salt (RRS) (Fig. 1）は pH 7 の水中で $365 \mathrm{~nm}$ の光照射を行うことに よりそれぞれ 0.0065 及び 0.069 の量子収率で分解 し NO 放出を起こすことが示されている. ${ }^{14)}$ RBS 及 び RRS の問題点としては，RBS の高い細胞毒性が 挙げられる。また，RRS が長期間の保存によって 徐々に RBS に変化していくため, RRS の使用にも 注意を要する.

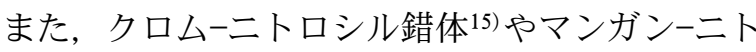
ロシル錯体, 16) ルテニウムーニトロシル錯体 ${ }^{17)}$ 等も 光作動型 NO ドナーとして報告されているが，遷

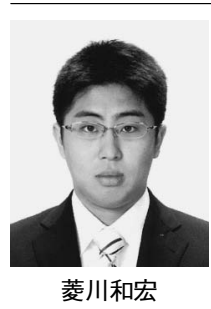

1984 年愛知県一宮市生まれ。 2007 年名 古屋市立大学薬学部卒業. 2009 年同大 学院薬学研究科博士前期課程修了. 現 在, 同大学院薬学研究科博士後期課程 在学中. 2006 年より宮田直樹教授の主 宰する薬化学分野にて二光子励起作動 型一酸化窒素供与剂の創製研究を行つ ている. 
移金属イオン由来と考えられる毒性がみられる化合 物もある.

2-4. 6-nitrobenzo $[a]$ pyrene $(6 \text {-nitroBaP })^{18)}$ 及び 2,6-dimethylnitrobenzene ${ }^{19)}$ 6-nitrobenzo $[a]$ pyrene（6-nitroBaP） はわれわれのグループが 2001 年に報告した光作動型 NO ドナーである（Fig.

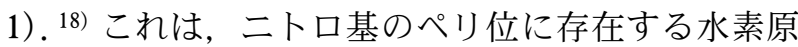
子の立体障害によりニトロ基が芳香環平面から大き く傾いているためにニトロ基の光異性化反応が起こ り易くなっており，異性化によって生じた亜硝酸工 ステルがホモリシス開裂を起こすことで NO 放出 が起こると考えられる。

それを基にわれわれは 2005 年に 2,6-dimethylnitrobenzene 誘導体が光照射で NO 放出を起こすこ とを報告した. ${ }^{19)}$ これは，二トロ基のオルト位に存 在するメチル基の立体障害によりニトロ基が芳香環 平面から大きく傾いているために二トロ基の光異性 化反応が起こり易くなるためと考えられる。

2,6-dimethylnitrobenzene 誘導体の問題点として は，2,6-dimethylnitrobenzene 誘導体の極大吸収波 長が，細胞障害性が高く組織透過性が低いUV-A 領域に存在するということである．医薬品への応用 を考えた場合，細胞障害性が低く組織透過性が高い 長波長の光で放出制御可能な NO ドナーの開発が 求められる。

\section{3. 二光子励起}

長波長の光で化合物を励起する方法の 1 つに二光 子励起がある. 二光子励起とは，一光子励起の場合 のおよそ倍の波長の光子 2 つをほぼ同時に吸収する
ことにより化合物が励起状態へと遷移する現象のこ とである. 二光子励起は 1931 年に Göppert-Mayer により予見された現象であるが, 20,21) 1961 年に Kaiser と Garrett らにより初めて実験的に観測され た. ${ }^{22)}$ その後, 1970 年代に波長可変色素レーザーが 実用化されベンゼンなどの有機化合物での二光子励 起が観測可能となった. ${ }^{23,24)}$ 近年では二光子励起に よる蛍光色素からの蛍光発光を利用した二光子蛍光 顕微鏡が開発され，実用化されるに至ってい る. ${ }^{25,26}$

一光子励起と二光子励起による $\mathrm{NO}$ 放出ついて 概略図を Fig. 2 に示した。一光子励起では分子は 光子 1 つを吸収して励起状態へと遷移する。励起状 態へと遷移した分子はそのエネルギーにより NO を放出しながら分解する，それに対して二光子励起 では一光子励起のおよそ半分のエネルギー，つまり 倍の波長の光子 2 つをほぼ同時に吸収して励起状態 へと遷移する，二光子励起を用いれば，例えば一光 子励起において $400 \mathrm{~nm}$ 付近に極大吸収波長を持つ 化合物は倍の $800 \mathrm{~nm}$ 付近の光照射によって NO 放 出を起こすことが可能となり，近赤外光で NO 放 出をコントロールすることが可能となる.

効率よく二光子励起を起こすことが知られている 構造として電子供与性基（donor）と電子求引性基 （acceptor）が donor- $\pi$-acceptor- $\pi$-donor 若しくは acceptor- $\pi$-donor- $\pi$-acceptor の形で結合した構造が 知られている. 27) また, fluorescein などの蛍光色素 も二光子励起を起こすことが知られている. ${ }^{28)}$

以下に二光子励起で作動する NO ドナーの例を (a)

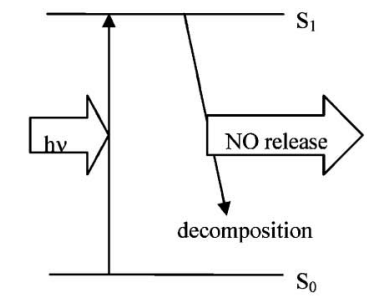

NO release by one-photon excitation (b)

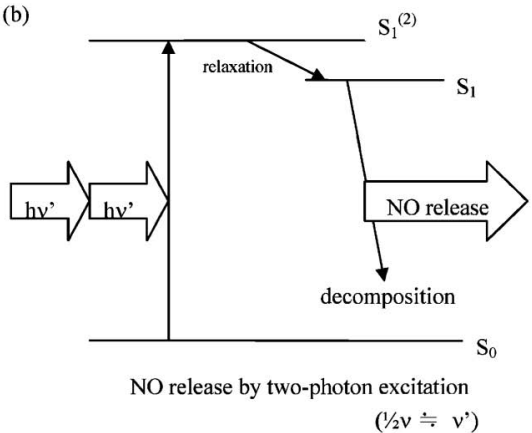

Fig. 2. Schematic View of NO Release in Response to OPE and TPE

In one-photon excitation (OPE), an NO releasing molecule in ground state $\left(\mathrm{S}_{0}\right)$ absorbs one photon and it transits to high energy level. If the molecule transits to higher energy levels than the lowest excited energy level, it relaxes to the lowest excited level $\left(\mathrm{S}_{1}\right)$ immediately. Then, the molecule decomposes with releasing NO By contrast, an NO releasing molecule absorbs two photons in two-photon excitation (TPE). The molecule transits to a two-photon excitation-allowed level ( $\left.\mathbf{S}_{1}^{(2)}\right)$ and it relaxes to the lowest excited level $\left(\mathrm{S}_{1}\right)$ immediately. Then, the molecule decomposes with releasing NO. 
挙げて説明する.

\section{4. 二光子励起で作動する NO ドナー}

4-1. PPIX-RSE ${ }^{29)}$ PPIX-RSE は Ford らに よって開発された二光子励起作動型の NO ドナー である（Fig. 3). 29) 本化合物は二光子励起を起こす ことが知られている Protoporphyrin IX (PPIX) ${ }^{30)}$ を光吸収アンテナ部位とし NO 放出部位である Roussin's red salt ester (RSE) ${ }^{14)}$ とつなげた構造で あり, PPIX の励起エネルギーが RSE 部分に移動 することでNO 放出が起こるよう設計されている.

PPIX-RSE の二光子励起による分解性能を評価 するための值としては二光子吸収断面積 $\delta_{\mathrm{a}}$ (二光

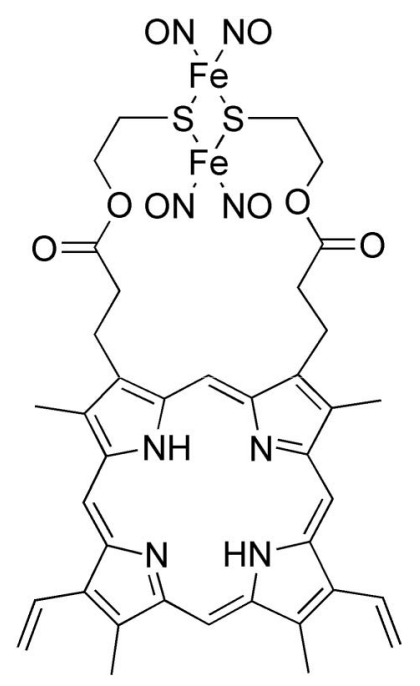

PPIX-RSE

Fig. 3. Structure of PPIX-RSE ${ }^{29)}$
子吸収の効率を示す值）と分解量子収率 $\Phi$ の両方 を求めるか, 二光子分解断面積 $\delta_{\mathrm{u}}$ (二光子吸収断 面積と分解量子収率の積) ${ }^{31}$ を求めるかの 2 つがあ るが，ともに求められておらず，Crambらにより 求められたPPIX の二光子吸収断面積 $\delta_{\mathrm{a}} 790 \mathrm{~nm}=2$ $\mathrm{GM}\left(\mathrm{GM}=10^{-50} \mathrm{~cm}^{4} \cdot \mathrm{s} \cdot\right.$ photon $\left.^{-1}\right)$ という值が分 かっているのみである. ${ }^{30)}$

PPIX-RSE は水溶性があまりよくなく，吸収ス ペクトルの測定や系中で発生した NO の測定は THF 溶液で行っている.

4-2. Fluor-RSE ${ }^{32)}$ Fluor-RSE は PPIX-RSE の欠点である溶解性の低さを改善し, また PPIX よりも大きな二光子吸収断面積を持った fluorescein ${ }^{28)}$ を光吸収アンテナ部位に用いた分子として Ford ら により開発された (Fig. 4). ${ }^{32)}$ Fluor-RSE も PPIX$\mathrm{RSE}$ と同様に, 光吸収アンテナ部位の励起エネル ギーが RSE 部分に移動することで NO 放出が起こ るように設計されている.

Fluor-RSE の $800 \mathrm{~nm}$ における二光子吸収断面積 は $\delta_{\mathrm{a} 800 \mathrm{~nm}}=63 \pm 7 \mathrm{GM}$ と求められた。これは, fluorescein のカルボキシル基をエチルエステル化し た化合物 Fluor-Et の二光子吸収断面積 $\delta_{\mathrm{a} 800 \mathrm{~nm}}=32$ \pm 3 GM のおよそ 2 倍であり, Fluor-RSE の構造中 に flourescein が 2 つ付いていることに一致する值 となっている.

また, Ford らは Fluor-RSE の NO 放出量子収率 も求めている. ${ }^{33)}$ 一光子励起と二光子励起の量子収 率は等しいと考えられており, 一光子励起による実

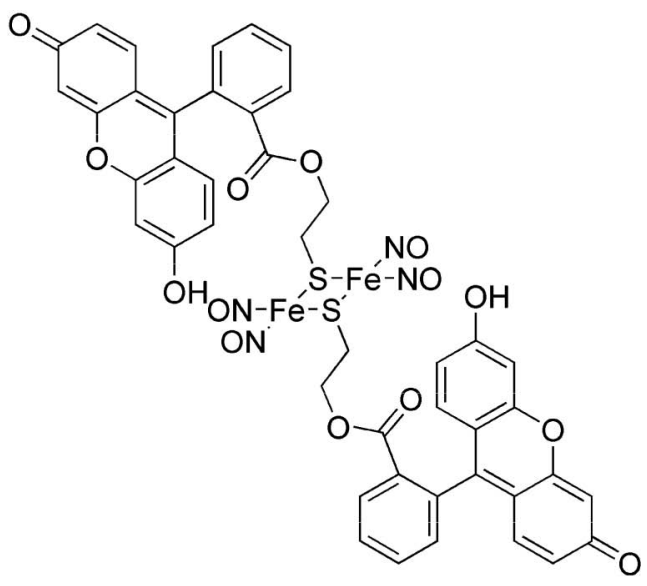<smiles>CCOC(=O)c1ccccc1-c1c2ccc(=O)cc-2oc2cc(O)ccc12</smiles>

Fluor-Et

Fluor-RSE

Fig. 4. Structures of Fluor-RSE and Fluor-Et ${ }^{32)}$ 
験から Fluor-RSE の NO 放出量子収率は $\Phi_{\mathrm{NO}}=$ $0.0036 \pm 0.005$ と求められた.

Fluor-RSE は PPIX-RSE に比べて水溶性が若干 改善されており，二光子吸収断面積や $\mathrm{NO}$ 放出量 子収率の測定においては $\mathrm{CH}_{3} \mathrm{CN} / \mathrm{H}_{2} \mathrm{O}$ の 50/50 溶 液を用いている。

4-3. AFX-RSE ${ }^{34)}$ AFX-RSE は Fluor-RSE よ りもさらに効率の高い二光子励起作動型 NO ド ナーの創製を目指して Ford らにより開発された化 合物であり, donor- $\pi$-acceptor- $\pi$-donor 型色素の $\mathrm{AF}$ chromophore ${ }^{35)}$ を $\mathrm{NO}$ 放出部位である RSE に 導入した化合物である（Fig. 5). ${ }^{34)}$ AF chromophore の励起エネルギーが RSE 部分に移動して $\mathrm{NO}$ 放出が起こるように設計されている.

AFX-RSE の二光子吸収断面積は $\delta_{\mathrm{a} 800 \mathrm{~nm}}=246 \pm$ $8 \mathrm{GM}$ と求められた。 AF chromophore にトシル基 を導入した AF-tosyl（AF343b）の二光子吸収断面 積は $\delta_{\mathrm{a} 800 \mathrm{~nm}} \sim 140 \mathrm{GM}$ であり, AFX-RSE の二光子 吸収断面積は AF343b のおよそ 2 倍である。これは AF chromophore 部分が 2 つ結合していることに合 致する結果であった。また，NO 放出の量子収率 $\Phi_{\mathrm{NO}}=0.0049 \pm 0.0009$ と求められた.

AFX-RSE は Fluor-RSE に比べ二光子吸収断面積 はおよそ 4 倍となり，また NO 放出量子収率も上
昇した。しかし，水溶性は低下し，化合物の評価は すべて THF 中で行われた結果である.

4-4. TP-M ${ }^{36)}$ TP-M は Prasad らによって報 告された二光子励起作動型 NO ドナーである（Fig. 6). ${ }^{36)}$ その構造は oligo-phenylene vinylene (OPV) ${ }^{37,38)}$ を光吸収アンテナ部位として RSE に導入すること で OPV の励起エネルギーが RSE 部分に移動して $\mathrm{NO}$ 放出が起こるように設計されている。また， OPV 部分に tetra（oligo (ethylene glycol) ) を導入 することで水溶性の向上も図っており，その結果 TP-M は最高 $5 \mathrm{mg} / \mathrm{ml}$ の濃度で水に溶けることが 分かっている。

TP-M の二光子吸収断面積 $\delta_{\mathrm{a}}$ は $682 \mathrm{GM}$ であ り，これは OPV 構造を Roussin's red salt 部分に結 合させる前の構造 TP-I の二光子吸収断面積 $\delta_{\mathrm{a}}=$ $370 \mathrm{GM}$ のほぼ 2 倍であり, OPV 構造が 2 つ結合 していることに一致する結果を示している。 また， TP-M の二光子吸収断面積は AFX-RSE の二光子吸 収断面積に比べ 2.8 倍程度大きい。ただし，NO 放 出の量子収率は求められていないため, AFX-RSE との性能の違いは単純に比較することはできない.

また，TP-M は二光子励起作動型 NO ドナーにお いて，二光子励起により放出された NO の殺細胞 効果が検討された初めての化合物でもある。その結

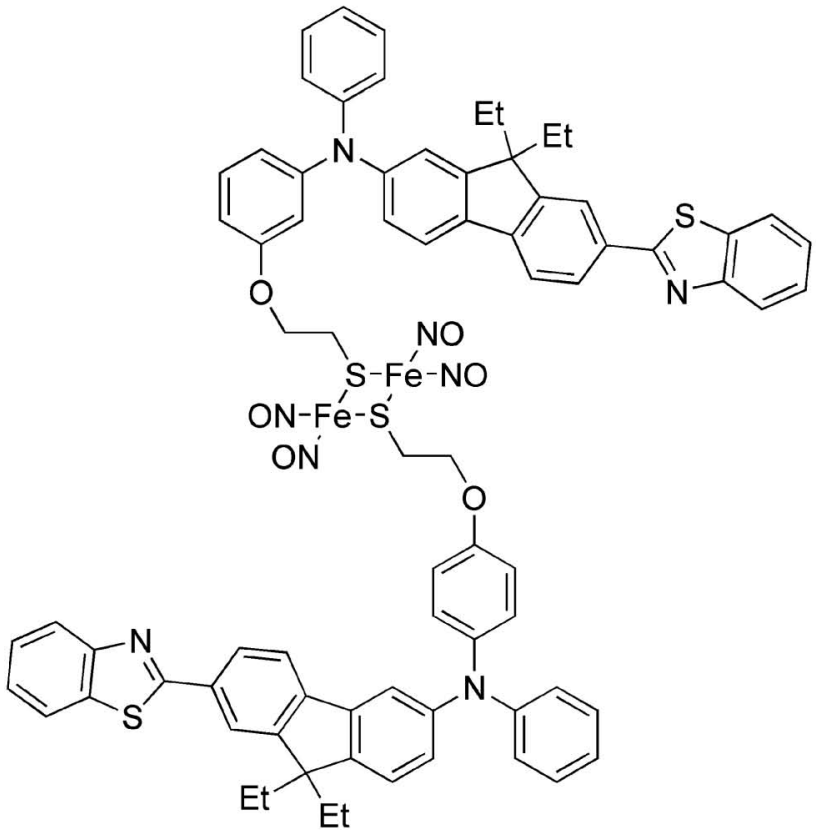

AFX-RSE

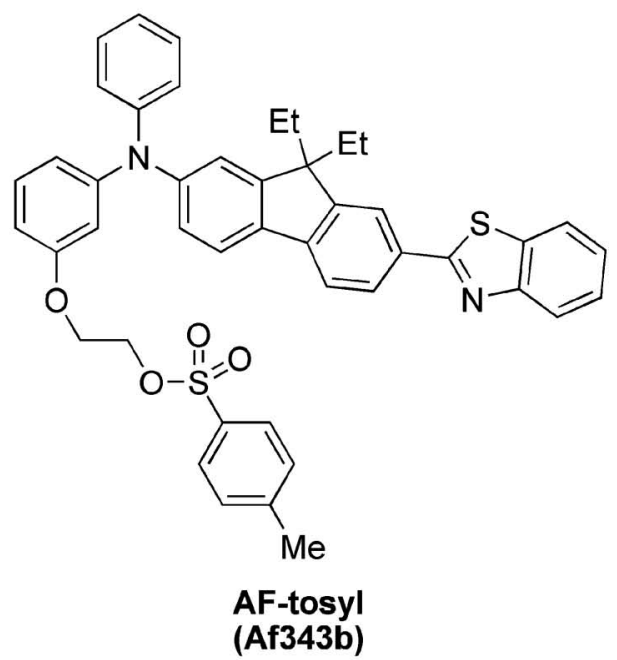

Fig. 5. Structures of AFX-RSE and AF-tosyl ${ }^{34)}$ 


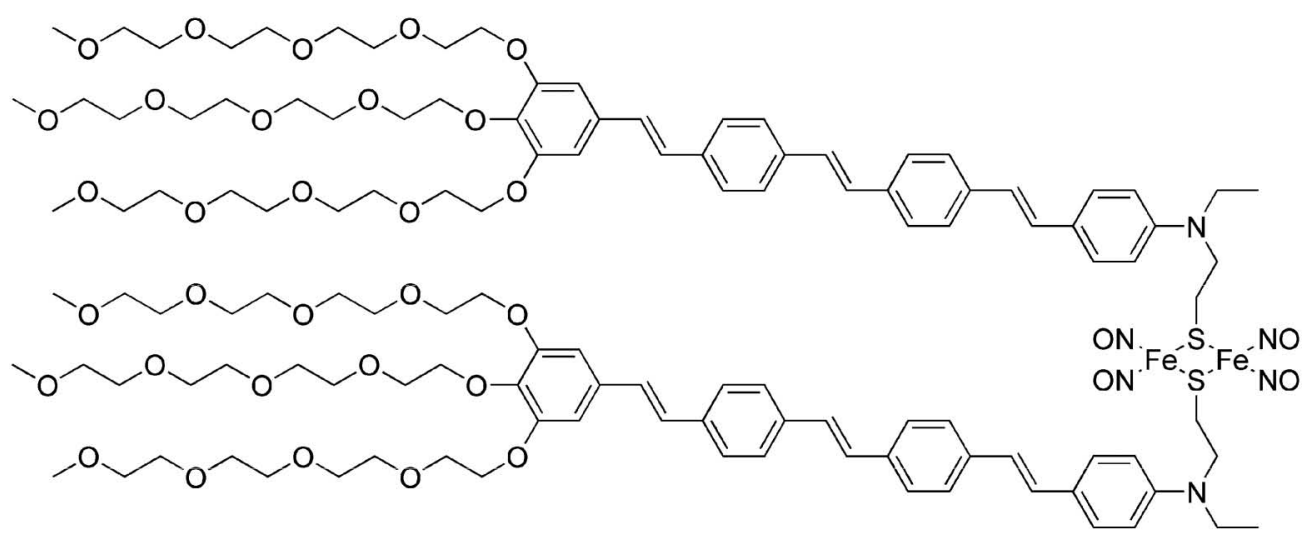

TP-M

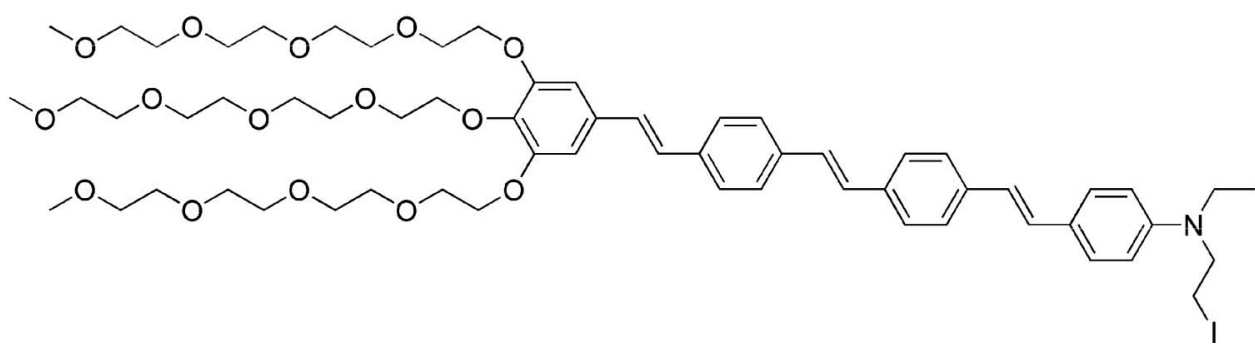

TP-I

Fig. 6. Structures of TP-M and TP-I ${ }^{36)}$

果，化合物投与後に光照射を行わなかつた細胞に対 してレーザー光照射を行った細胞では細胞死が誘導 されるという結果が示された。しかし，レーザー光 非照射の細胞においても細胞死が誘導されており, 化合物自体の毒性が高いと考えられるため, 細胞系 への応用には適さないと思われる.

\section{4-5. Flu-DNB ${ }^{39)}$ Flu-DNB はわれわれが開発} した二光子励起作動型 NO ドナーであり, 光吸収 アンテナ部位として fluorescein ${ }^{28)}$ を, NO 放出部位 としてわれわれが開発した 2,6-dimethylnitrobenzene 構造 ${ }^{19)}$ を導入した化合物である（Fig. 7). ${ }^{39)}$ 光 吸収アンテナ部位と NO 放出部位の間をスチリル 基及び弱い二重結合性を持ったアミド結合を介して つなぐことで fluorescein の励起エネルギーが 2,6dimethylnitrobenzene 構造に移動し NO 放出を起こ すことを期待した設計であったが，一光子励起実験 において fluorescein の励起波長域である 450-480 $\mathrm{nm}$ の光照射を行っても NO 放出が起こらなかっ た. しかし， 330-380 $\mathrm{nm}$ の光照射を行ったところ $\mathrm{NO}$ 放出が観察された。このことから，本化合物で は恐らくスチルベン部分が二光子吸収を起こして NO 放出が起こっていると考えられる.<smiles>COc1cc(/C=C/c2ccc(C(=O)Nc3ccc(-c4c5ccc(=O)cc-5oc5cc(O)ccc45)cc3)cc2)cc([N+](=O)[O-])c1[N+](=O)[O-]</smiles>

Flu-DNB

Fig. 7. Structure of Flu-DNB ${ }^{39)}$

Flu-DNB の二光子吸収による NO 放出の性能は 二光子分解断面積 $\delta_{\mathrm{u}}{ }^{32)}$ により評価し，その結果， 二光子分解断面積は $720 \mathrm{~nm}$ で $0.12 \mathrm{GM}$ という結果 であった。

4-6. TB2-DNB 及びその関連化合物 ${ }^{40)}$ TB1DNB，TB2-DNB，DB1-DNB，DB2-DNB はわれわれ が開発した二光子励起作動型 NO ドナーである (Fig. 8).40)これらの化合物は Kamada らにより開 発された二光子励起作動型の蛍光色素である MPPBT そデルに設計した化合物である. ${ }^{41}$ 


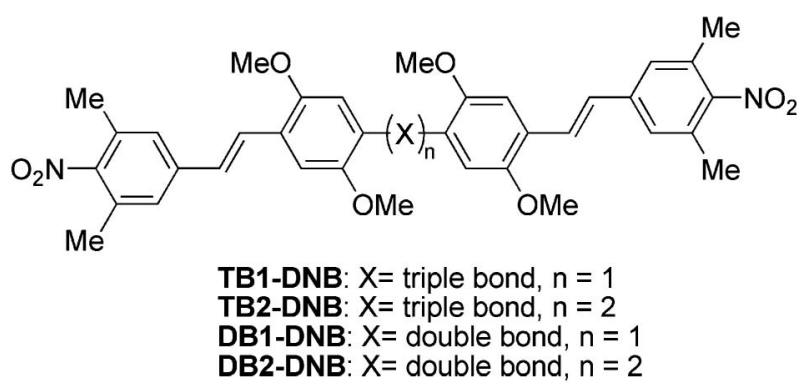

Fig. 8. Structures of TB1-DNB, TB2-DNB, DB1-DNB, and DB2-DNB ${ }^{40)}$

MPPBT の構造は acceptor である $N$-メチルピリジ ニウムと donor であるジメトキシベンゼンが多重 結合を介して接続され，効率よく二光子励起される ことが知られている acceptor- $\pi$-donor- $\pi$-acceptor の形で結合している。 TB2-DNB 類化合物では MPPBT の $N$-メチルピリジン部分を電子求引性基 かつ NO 放出部位である 2,6-dimethylnitrobenzene で置き換え，また中心の多重結合部分の種類と数を 変化させた.

4 つの化合物の二光子分解断面積を測定した結 果，一番大きな二光子吸収断面を持つ化合物は TB2-DNB であり，その時の二光子吸収断面積 $\delta_{\mathrm{u}}$ は 0.051 であった。これは Flu-DNB とは照射して いる波長が異なるので一概には比較できないものの, Flu-DNB の二光子吸収断面積と比べると小さい. 理由として，多重結合部分の回転によりエネルギー が消費され NO 放出に効率よく使用されていない 可能性や，2,6-dimethylnitrobenzene 構造の電子求 引性が低く, acceptor- $\pi$-donor- $\pi$-acceptor $の$ 構造に おいて分極率が高くない可能性が考えられる.

\section{5. 今後の課題}

これまでに紹介したように，二光子励起で作動す る NO ドナーはそれぞれに欠点を持っており，そ の研究はいまだ発展途上である。例えば，確立され た評価系が存在しないため，その性能を比較するた めの值も統一されておらず，各化合物の二光子励起 による NO 放出効率を直接比較することは難し い. また，化合物を二光子励起させるために必要な パルスレーザーも容易に手に入るものではなく，ま た生体内部にパルスレーザー光を誘導するための装 置の開発もあまり行われてはいない.

しかし，二光子励起で作動する $\mathrm{NO}$ ドナーの開 発は，医薬品としての応用も考えられる非常に魅力
的な分野である，今後，さらに効率よく二光子励起 でNO を放出する化合物の創製を目指してさらな る研究を行っていきたい.

\section{REFERENCES}

1) Ignarro L. J., Buga G. M., Wood K. S., Byrns R. E., Chaudhuri G., Proc. Natl. Acad. Sci. USA, 84, 9265-9269 (1987).

2) Palmer R. M., Ferige A. G, Moncada S., $\mathrm{Na}$ ture, 327, 524-526 (1987).

3) Schuman E. M., Madison D. V., Science, 254, 1503-1506 (1991).

4) Stamler J. S., Singel D. J., Loscalzo J., Science, 258, 1898-1902 (1992).

5) Schuman E. M., Madison D. V., Science, 263, 532-536 (1993).

6) Cifone M. G., Cironi L., Meccia M. A., Roncaioli P., Festuccia C., De Nuntiis G., D'Alo S., Santoni A., Adv. Neuroimmunol., 5, 443461 (1995).

7) Xie B. K., Huang S., Dong Z., Juang S.-H., Gutman M., Xie Q., Nathan C., Fidler I. J., J. Exp. Med., 181, 1333-1343 (1995).

8) Wang P. G., Xian M., Tang X., Wu X., Wen Z., Cai T., Janczuk A. J., Chem. Rev., 102, 1091-1134 (2002).

9) Makings L. R., Tsien R. Y., J. Biol. Chem., 269, 6282-6285 (1994).

10) Maragosa C. M., Morley D., Wink D. A., Dunams T. M., Saavedra J. E., Hoffman A., Bove A. A., Issac L., Hrabie J. A., Keefer L. K., J. Med. Chem., 34, 3242-3247 (1991).

11） Hrabie J. A., Klose J. R., Wink D. A., Keefer L. K., J. Org. Chem., 58, 1472-1476 (1993).

12) Namiki S., Arai T., Fujimori K., J. Am. Chem. Soc., 119, 3840-3841 (1997).

13) Namiki S., Kaneda F., Ikegami M., Arai T., Fujimori K., Asada S., Hama H., Kasuya Y., Goto K., Bioorg. Med. Chem., 7, 1695-1702 (1999).

14) Bourassa J., DeGraff W., Kudo S., Wink D. A., Mitchell J. B., Ford P. C., J. Am. Chem. Soc., 119, 2853-2860 (1997).

15) Neuman D., Ostrowski A. D., Absalonson R. O., Strouse G. F., Ford P. C., J. Am. Chem. Soc., 129, 4146-4147 (2007).

16) Eroy-Reveles A. A., Leung Y., Beavers C. M., Olmstead M. M., Mascharak P. K., J. Am. 
Chem. Soc., 130, 4447-4458 (2008).

17) Rose M. J., Fry N. L., Marlow R., Hinck L., Mascharak P. K., J. Am. Chem. Soc., 130, 8834-8846 (2008).

18) Fukuhara K., Kurihara M., Miyata N., J. Am. Chem. Soc., 123, 8662-8666 (2001).

19) Suzuki T., Nagae O., Kato Y., Nakagawa H., Fukuhara K., Miyata N., J. Am. Chem. Soc., 127, 11720-11726 (2005).

20) Göppert-Mayer M., Ann. Phys., 9, 273-294 (1931).

21) Göppert-Mayer M., Ann. Phys., 18, 466-479 (2009) .

22) Kaiser W., Garrett C. G. B., Phys. Rev. Lett., 7, 229-231 (1961).

23) Bradley D. J., Hutchinson M. H. R., Koetser H., Morrow T., New G. H. C., Petty M. S., Proc. R. Soc. Lond. A, 328, 97-121 (1972).

24) Bradley D. J., Hutchinson M. H. R., Koetser H., Proc. R. Soc. Lond. A, 329, 105-119 (1972).

25) Denk W., Strickler J. H., Webb. W. W., Science, 248, 73-76 (1990).

26) Svoboda K., Denk W., Kleinfield D., Tank D. W., Nature, 385, 161-165 (1997).

27) Albota M., Beljonne D., Bredas J.-L., Ehrlich J. E., Fu J.-Y., Heikal A. A., Hess S. E., Kogej T., Levin M. D., Marder S. R., McCord-Maughon D., Perry J. W., Rockel H., Rumi M., Subramaniam G., Webb W. W., Wu X.-L., Xu C., Science, 281, 16531656 (1998).

28) Xu C., Webb W. W., J. Opt. Soc. Am. B, 13, 481-491 (1996).

29) Wecksler S., Mikhailovsky A., Ford P. C., J. Am. Chem. Soc., 126, 13566-13567 (2004).

30) Goyan R. L., Cramb D. T., Photochem. Pho- tobiol., 72, 821-827 (2000).

31) Furuta T., Wang S. S.-H., Dantzker J. L., Dore T. M., Bybee W. J., Callaway E. M., Denk W., Tsien R. Y., Proc. Natl. Acad. Sci. USA, 96, 1193-1200 (1999).

32) Wecksler S., Mikhailovsky A., Korystov D., Ford P. C., J. Am. Chem. Soc., 128, 38313837 (2006).

33) Wecksler S., Hutchinson J., Ford P. C., Inorg. Chem., 45, 1192-1200 (2006).

34) Wecksler S., Mikhailovsky A., Korystov D., Buller F., Kannan R., Tan L.-S., Ford P. C., Inorg. Chem., 46, 395-402 (2007).

35) He G. S., Lin T.-C., Dai J., Prasad R. N., Kannan R., Dombroskie A. G., Vaia R. A., Tan L.-S., J. Chem. Phys., 120, 5275-5284 (2004).

36) Zheng Q., Bonoiu A., Ohulchanskyy T. Y., He G. S., Prasad R. N., Mol. Pharm., 5, 389398 (2008).

37) Reinhardt B. A., Brott L. L., Clarson S. J., Dillard A. G., Bhatt J. C., Kannan R., Yuan L., He G. S., Prasad P. N., Chem. Mater., 10, 1863-1874 (1998).

38) Ventelon L., Charier S., Moreaux L., Mertz J., Blanchard-Desce M., Angew. Chem. Int. Ed., 40, 2098-2101 (2001).

39) Hishikawa K., Nakagawa H., Furuta T., Fukuhara K., Tsumoto H., Suzuki T., Miyata N., J. Am. Chem. Soc., 131, 7488-7489 (2009).

40) Hishikawa K., Nakagawa H., Furuta T., Fukuhara K., Tsumoto H., Suzuki T., Miyata N., Bioorg. Med. Chem. Lett., 20, 302-305 (2010).

41) Iwase Y., Kondo K., Kamada K., Ohta, K., J. Mater. Chem., 13, 1575-1581 (2003). 